\title{
自然風による鉄塔支持型煙突の不規則振動に 関する実測と解析*

\author{
MEASUREMENTS AND RESPONSE ANALYSIS ON RANDOM VIBRATION \\ OF A STACK WITH TOWER DUE TO NATURAL WIND
}

\author{
薄 木 征 三** • 山 家 義 雄***.色 部 誠**** \\ By Seizo Usuki, Yoshio Yambe and Makoto Irobe
}

\section{1. 緒言}

排煙処理技術の開発途上にあっては煙突の大型化，特 にこれを高くすることは，拔本的煙害対策とはならない がとらざるを得ない一つの措置である。煙突を高くする 場合，支持鉄塔は剛性を高点に扔いて構造上きわめ て有効な方法である。しかし，自然風の中に置かれた鉄 塔支持型煙突の挙動を正しく評価し, 煙突の設計ならび に安定性に正当な指標を与えることは困難な問題であ る。このおもな原因は, 何本かの柱材によって立体的に 組みたてられた断面であるから, 煙突は自然風そのもの の乱れをうけるのみならず，部材による流れの擋乱によ ってさらに複雑な乱流の影響を受け，したがって煙突全 体に作用する風力の算定が困難であるという点にある。 この点に扔いて地震動による応答と本質的な相違がある わけであり, その研究の歴史も新しいものであるといえ よう。

鉄塔支持型煙突の風による振動の発生原因を，巨視的 な観点から, 空力弾性論に準じて考えてみると, 自然風 の乱れ, カルマン渦, ほかの構造物の後流渦列によるバ フェッティング, 不安定現象に属するフラッター, さら にこれらのいくつかの組み合わせなどとなろう。このう ち, バフェッティングは煙突の周囲の環境によるもので あるから，当面対象外とする。またフラッターは，煙突 のような柱状の 2 軸対称構造では, 航空機の翼のような 曲げねじりフラッターは起こりにくいと思われる。もっ とも可能性のあるものとして, 自然風の乱れとカルマン

\footnotetext{
* "Proc. 20 th Japan National Congress for Applied Mechanics, 1970”に一部発表したが，計算にミスがあ ったことと，新しい凘料を加え訂正，加筆したものであ る。

** 正会是

*** 正会员

**** 此会員

秋洲大学講帥 鉱山学部土木工学科 東北電力 (株) 土木部長

工怔 秋田大学教授 鉱山学部土木工学科
}

渦によるものが考えられているが，実在の鉄塔支持型煙 突について定性的にも, 定量的にも実証がなされている 例はきわめて少なく，観測記録が報告されるようになっ たのも比較的最近のことであり，いまだ十分な解明がな されているとはいえないのが実情である。本報告は, 煙 突のいわゆる予想臨界風速以下の風を対象として, 線状 構造物としての不規則振動論の立場から加速度応答の実 測値と理論計算值との検証を行なったものである。

本鉄塔支持型煙突は, 東北電力（株）秋田火力発電所 の高さ $150 \mathrm{~m}$ のものであり, 煙突上 2 か所に風速計と 加速度計が設置されており，いずれも水平直交 2 成分が 同時に観測されるようになっている。解析は, 煙突を 2 自由度振動系として表示し, 風速スペクトルの 3 次元解 析を行ない, 応答スペクトルを計算している。従来, 1 自由度系の不規則外乱による応答スペクトルについての 論文ならびに解析結果は数多く見られるが, 多自由度系 については論文は多いが実測值と理論值を比較している ものは少ない。

\section{2. 多自由度多入カ系のスペクトル理論}

\section{(1) 一般理論}

2 自由度系の不規則振動論には Davenport ${ }^{1)}$ の上界 評価法, 石崎 ${ }^{2}$ の上下界評価法があるが，ここでは一般 的な多自由度系の場合の解析手順を示す。

多自由度多入力系の線形不規則振動論は, すでに完成 された感がありいくつかの成書にもなっており ${ }^{3)}$ 種々の 振動系への理論上の応用もなされている。したがって, ここでは数值計算に必要な要点のみを述べるにとどめ る。

基本となる振動方程式は次式である。

$$
[M]\{\ddot{u}\}+[C]\{\dot{u}\}+[K]\{u\}=\{f\}
$$$$
\text { ここに }
$$ 

$[M]$ : 質䭪マトリックス
$[C]$ : 減衰マトリックス
$[K]:$ 岡性マトリックス
$\{u\}$ : 変位ベクトル
$\{f\}$ : 外乱（風力）ベクトル

である。式 (1) の解は

$$
\{u\}=\int_{-\infty}^{\infty}[h(t-\tau)]\{f(\tau)\} d \tau
$$

ここに $[h(t)]$ はインパルス応答関数である。

風力ベクトル $\{f(t)\}$ が定常エルゴード確率過程に従 うものと仮定するならば，式 (2) の相関関数における関 係は次のようである。

$$
\begin{aligned}
{\left[R_{u}(\tau)\right]=} & \lim _{T \rightarrow \infty} \frac{1}{2 T} \int_{-T}^{T}\{u(t)\}\{u(t+\tau)\}^{T} d \tau \\
= & \int_{-\infty}^{\infty} \int_{-\infty}^{\infty}\left[h\left(\tau_{1}\right)\right]\left[R_{f}\left(\tau+\tau_{1}-\tau_{2}\right)\right] \\
& \cdot\left[h\left(\tau_{2}\right)\right]^{T} d \tau_{1} d \tau_{2} \ldots \ldots \ldots \ldots \ldots \ldots \ldots
\end{aligned}
$$

$こ こ に$

$$
\begin{aligned}
& {\left[R_{u}(\tau)\right] \text { : 応答変位相関関数 }} \\
& {\left[R_{f}(\tau)\right]: \text { 風力相関関数 }}
\end{aligned}
$$

であり,これらの対角要素が自己相関関数, 非対角要素 が相互相関関数である。式 (3) の周波数領域における関 係は, Wiener-Khinchin の法則によって次のようであ る。

$$
\left\lfloor S_{u}(\omega)\right]=\left\lfloorH ( \omega ) | ^ { * } [ S _ { f } ( \omega ) ] \left[\left. H(\omega)\right|^{T} \cdots \cdots(4)\right.\right.
$$$$
\text { ここに }
$$

$\left[S_{u}(\omega)\right]:$ 応答変位パワースペクトル

$\left[S_{f}(\omega)\right]:$ 風力パワースペクトル

$[H(\omega)]$ : 周波数応答関数

であり，*は共役マトリックス， $T$ は転置マトリックス を表わす。 $\left[S_{u}(\omega)\right],\left[S_{f}(\omega)\right]$ の対角要素はパワースペ クトル密度, 非対角要素はクロスパワースペクトル密度 である。 $[H(\omega)]$ は次式によって与えられる。

$$
[H(\omega)]=\left[-\omega^{2} M+i \omega \dot{C}+K\right]^{-1}
$$

$i$ は虚数単位である。

忘答変位のパワースペクトルを用いれば，応答速度， 加速度のそれは次のようである。

$$
\begin{aligned}
& {\left[S_{\dot{u}}(\omega)\right]=\omega^{2}\left[S_{u}(\omega)\right]} \\
& {\left[S_{\ddot{u}(\omega)]}=\omega^{4}\left[S_{u}(\omega)\right]\right.}
\end{aligned}
$$

\section{（2）モーダルアナリシス}

本鉄塔支持型煙突の減衰率は非常に小さいので (3. 参 照)，モーダルアナリシス法を適用して計算を行なった。 振動方程式 (1) の固有振動モードを $[\Phi]$ で表わすと

$$
\left.\begin{array}{rl}
{[\Phi]^{T}[M][\Phi]} & =\left[m_{\mathrm{\prime}}\right] \\
{[\Phi]^{T}[K][\Phi]} & =\left[k_{\mathrm{V}}\right] \\
{[\Phi]^{T}[C][\Phi]} & =\left[c_{\mathrm{V}}\right]
\end{array}\right\}
$$

ここに [’、は対角マトリックスを表わす。式 (8) を
式 (5) に代人すれば,

$$
[H(\omega)]=[\Phi][\because]^{-1}\lfloor\Phi]^{T}
$$

式 (9)の要素 $Z_{j}$ は次式である。

$$
Z_{j}=m_{j}\left(-\omega^{2}+\omega_{j}{ }^{2}+2 \beta_{j} \cdot \omega_{j} \cdot \omega \cdot i\right)
$$

ここに

$$
\left.\begin{array}{rl}
\omega_{j}{ }^{2} & =k_{j} / m_{j} \\
2 \beta_{j} \omega_{j} & =c_{j} / m_{j}
\end{array}\right\}
$$

であり, $m_{j}, k_{j}, c_{j}$ は式 (8) の対角要素である。式 (9) を加速度パワースペクトル式 (7) に代入すれば次のよう である。

$$
\begin{aligned}
{\left[S_{i i}(\omega)\right]=} & \omega^{4}[\Phi]\left([Z]^{-1}\right) *[\Phi]^{T}\left[S_{f}(\omega)\right] \\
& \cdot[\Phi]\left([Z]^{-1}\right)^{T}[\Phi]^{T} \ldots \ldots \ldots \ldots \ldots \ldots
\end{aligned}
$$

実際，計算は電子計算機によることになるが，これら マトリックス表示によって計算をすすめるのが誤りを防 ぐらえにも有効である。

\section{（3）風力の評価}

図一1 のように質点 $i$ での鉄塔支持型煙突の断 喕に作用する抗力による 風力は，風の加速度によ る慣性項を無視すると

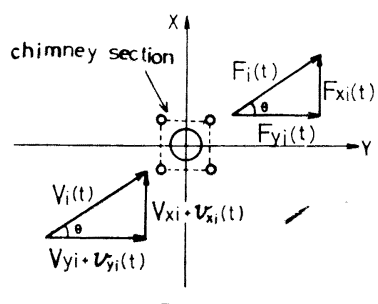

図 1

$$
F_{i}(t)=\frac{1}{2} \rho A_{i} C_{D i} V_{i}^{2}(t)
$$

ここに $\rho$ は空気密度， $A_{i}, C_{D i}, V_{i}($ ( ) は打のお筫 点 $i$ に係る受風面積, 抗力係数, 風速である。煙突筒 身外径を $D$, 質点 $i$ に係る長さを $L_{i}$, 円柱の抗力係数 を $C_{D_{0}}$ とすれば式 (13) は,

$$
F_{i}(t)=\frac{1}{2} \rho D L_{i} \cdot C_{D_{0}} g_{i}(\theta) \cdot V_{i}{ }^{2}(t)
$$

ここに $g_{i}(\theta)$ は, 風向角 $\theta(t)$ によって定まる $C_{D 0}$ に対する倍率である4)。式 (14) において

$$
\frac{1}{2} \rho D L_{i} C_{D 0} g_{i}(\theta) \equiv \eta_{i}
$$

とおき, 図一1 に示すように $X, Y$ おのおのの方向の風 速を (平均) + (変動) の形で表わし, 変動揚力を考慮し なければ, $X$ 方向成分の風力は

$$
\begin{aligned}
F_{x i}(t)= & F_{i}(t) \cdot \sin \theta \\
= & \eta_{i} V_{i}{ }^{2}\left(V_{x i}+v_{x i}\right) / V_{i} \\
= & \eta_{i} \sqrt{V_{x i}{ }^{2}+V_{y i}{ }^{2}} \\
& \cdot \sqrt{1+\frac{2\left(V_{x i} v_{x i}+V_{y i} v_{y i}\right)+v_{x i}{ }^{2}+v_{y i}{ }^{2}}{V_{x i}{ }^{2}+V_{y i}{ }^{2}}} \\
& \cdot\left(V_{x i}+v_{x i}\right) \\
\text { ここで, } & v_{x i}, v_{y i} \text { の2 次以上の項を無視すれば, } \\
= & \eta_{i} V_{x i} \sqrt{V_{x i}{ }^{2}+V_{y i}{ }^{2}} \\
& +\eta_{i} \frac{\left(2 V_{x i}{ }^{2}+V_{y i}{ }^{2}\right) v_{x i}+V_{x i} V_{y i} v_{y i}}{\sqrt{V_{x i}{ }^{2}+V_{y i}{ }^{2}}}
\end{aligned}
$$

同様に $Y$ 方向成分の風力は, 


$$
\begin{aligned}
F_{y i}(t)= & \eta_{i} V_{y i} \sqrt{V_{x i}{ }^{2}+V_{y i}{ }^{2}} \\
& +\eta_{i} \frac{\left(2 V_{y i}{ }^{2}+V_{x i}{ }^{2}\right) v_{y i}+V_{x i} V_{y i} v_{x i}}{\sqrt{V_{x i}{ }^{2}+V_{y i}{ }^{2}}}
\end{aligned}
$$

である。 $\eta_{i}$ を時間的に一定と仮定するならば, 式 (16), (17) の第 1 項は平均風速による静的外力であり，第 2 項が外力ベクトル $\{f\}$ の質点 $i$ における表示式とな る。したがって, 本節 (1), (2) における風カスペクトル $\left[S_{f}(\omega)\right]$ は $X$ 方向には式 (16) を，Y方向には式 (17) を用いておのおの独立に(ただし風速成分は，X，Y2 方向成分, $v_{x i}, v_{y i}$ を含んで）計算される。たとえば $X$ 方向の振動について考えるならば, 式 (3) の相関関数 $\left[R_{f}(\tau)\right]$ の $i$ 行 $j$ 列の要素 $R_{f i j}(\tau)$ は,

$$
\begin{aligned}
R_{f i j}(\tau)= & \lim _{T \rightarrow \infty} \frac{1}{2 T} \int_{-T}^{T} f_{x i}(t) f_{x j}(t+\tau) d \tau \\
= & \left(\eta_{i} / V_{i}\right)\left(\eta_{j} / V_{j}\right) \cdot\left\{\left(V_{i}{ }^{2}+V_{x i}{ }^{2}\right)\left(V_{j}{ }^{2}+V_{x j}{ }^{2}\right)\right. \\
& \cdot R_{x i x i}(\tau)+\left(V_{i}{ }^{2}+V_{x i}{ }^{2}\right) V_{x j} V_{y j} \cdot R_{x i y j}(\tau) \\
& +\left(V_{j}{ }^{2}+V_{x j}{ }^{2}\right) V_{x i} V_{y i} \cdot R_{y i x j}(\tau) \\
& \left.+V_{x i} V_{y i} V_{x j} V_{y j} \cdot R_{y i y j}(\tau)\right\} \cdots \cdots \cdots(18)
\end{aligned}
$$

\section{ここにたとえば}

$$
R_{x i y j}(\tau)=\lim _{T \rightarrow \infty} \frac{1}{2 T} \int_{-T}^{T}{ }^{v} x i(t) v_{y j}(t+\tau) d \tau
$$

などであり

$$
V_{i}=\sqrt{V_{x i}{ }^{2}+V_{y i}{ }^{2}}
$$

である。すなわち, $V_{i}$ は $i$ 点における平均風速, $R_{x i y j}(\tau)$ は質点 $i$ の $X$ 方向変動風速と質点 $j$ の $Y$ 方向変動風速の相互相関関数である。式 (18) の両辺の フーリェ変換を行なえば, 風力パワースペクトル $\left[S_{f}\right.$ $(\omega)] の i$ 行 $j$ 列要素は次のようである。

$$
\begin{aligned}
S_{f i j}(\omega)= & \left(\eta_{i} / V_{i}\right)\left(\eta_{j} / V_{j}\right) \cdot\left\{\left(V_{i}{ }^{2}+V_{x i}{ }^{2}\right)\left(V_{j}{ }^{2}+V_{x j}{ }^{2}\right)\right. \\
& \cdot S_{x i x j}(\omega)+\left(V_{i}{ }^{2}+V_{x i}{ }^{2}\right) V_{x j} V_{y j} \cdot S_{x i y j}(\omega) \\
& +\left(V_{j}{ }^{2}+V_{x j}{ }^{2}\right) V_{x i} V_{y i} \cdot S_{y i x j}(\omega) \\
& \left.+V_{x i} V_{y i} V_{x j} V_{y j} \cdot S_{y i y j}(\omega)\right\} \cdots \cdots \cdots . . .(19)
\end{aligned}
$$

ここにたとえば $S_{x i y j}(\omega)$ は, $i$ 点の $X$ 方向変動風 速と $j$ 点の $Y$ 方向変動風速との間のクロスパワースペ クトルである。 $Y$ 方向の振動についても類似の関係が 得られる。

本鉄塔支持型煙突は, 地上 $76 \mathrm{~m}$ と $135 \mathrm{~m}$ の 2 点で, $X, Y 2$ 成分の変動風速が同時に測定されている。した がって, $i, j=1,2$ であるから，

$$
\left[S_{f}(\omega)\right]=\left[\begin{array}{ll}
S_{f_{11}}(\omega) & S_{f_{12}(\omega)} \\
S_{f_{21}(\omega)} & S_{f_{22}(\omega)}(
\end{array}\right] .
$$

であり, 式 (19) から求めるべきパワースペクトルのう

ち, 独立なものは次の 10 種である。

点 1 について: $S_{x_{1} x_{1}}(\omega), S_{x_{1} y_{1}}(\omega), S_{y_{1} y_{1}}(\omega)$

点 2 について: $S_{x_{2 x 2}}(\omega), S_{x_{2} y_{2}}(\omega), S_{y_{2} y_{2}}(\omega)$

点 1 と点 2 の相互について:

$$
S_{x_{1} x_{2}}(\omega), S_{x_{1} y_{2}(\omega),} S_{y_{1} y_{2}}(\omega), S_{x_{2} y_{1}(\omega)}
$$

残りの 2 種 $S_{x 2 x_{1}}(\omega), S_{y_{2} y_{1}}(\omega)$ は* を共役記号とし $\tau$

$$
\begin{aligned}
& S_{x 2 x_{1}}(\omega)=S_{x_{1 x} x_{2}} *(\omega) \\
& S_{y_{2} y_{1}}(\omega)=S_{y_{1} y_{2}} *(\omega)
\end{aligned}
$$

によって求める。

以上において， $\eta_{i}$ を時間的に一定と仮定していること の物理的意味は次のようである。

すなわち, 変動風向角 $\theta(t)$ の近傍においては, 抗力 係数 $\left(g_{i}(\theta)\right)$ の変化は平滑であるとすることである。し たがって, 角柱材のような陵角を有する部材から成る構 造についてはこのような仮定は適当でないと思われる。 本鉄塔支持型煙突は支柱材に鋼管を用いていること, 支 柱材と煙突筒身径との比が非常に小さいことから， 5 . (1) でふれるように $g_{i}(\theta)$ の変化は緩慢なものである。 それゆえ上述の仮定を近似的に満たすものと思われる。

また，いわゆる空力アドミッタンスは 1 とみなしてい る。この点については, 計算結果の考察 5. (3) で言及す る。

\section{3. 鉄塔支持型煙突の 2 自由度表示}

本煙突の外形は，図一2 のようである。鉄塔と筒身 は, 地上 $25.5 \mathrm{~m}, 46 \mathrm{~m}, 76 \mathrm{~m}, 100 \mathrm{~m}, 119 \mathrm{~m}, 135 \mathrm{~m}$ の 6 か所に拉いてリング接合されている。これを, これら 接合点間ごとに一様断面を持つ等価な鉛直片持はりに置 きかえ，かつ筒身が露出している地上 $135 \mathrm{~m}$ と $150 \mathrm{~m}$ との中間にも節点をもうけ, 図一3 (a) に示すような 8 自由度としての剛性マトリックスを求めた。次に, マ ス・コンデンセイション (Mass Condensation) の手法

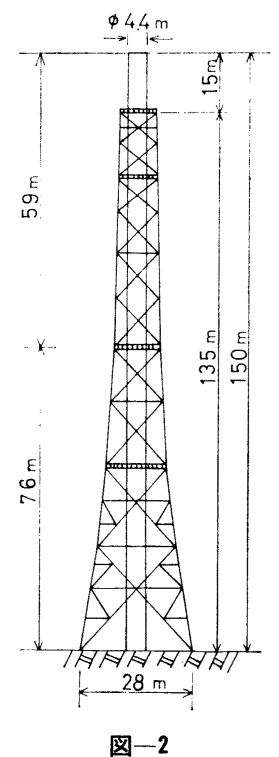

图-2 を用い, 8 自由度のらち, 風 速と加速度の測定されている 地上 $76 \mathrm{~m}$ と $135 \mathrm{~m}$ の節点 変位を選び, 2 自由度として の固有值および固有モードを 求めた (図一3(b) 参照)。

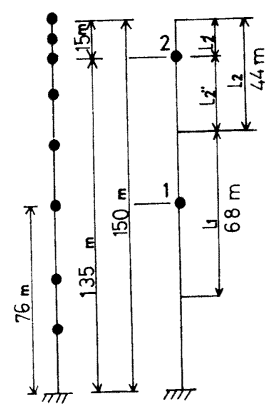

(a) 図-3 
この方法によれば，はじめから単に 2 自由度として計 算するよりも精度の良い結果が得られる。これら 2 点を 風力の作用点とすることによって，2. での手法により 解析を行なった。

計算に必要な諸量を以下に示す。ただし，地上 $76 \mathrm{~m}$ を節点番点 $1,135 \mathrm{~m}$ を番号 2 とする（以下この約束 にしたがう)。

$$
\begin{aligned}
& {[K]=\left[\begin{array}{rr}
35865 & 6871 \\
6871 & 3943
\end{array}\right](\mathrm{kg} / \mathrm{cm})} \\
& {[M]=\left[\begin{array}{rr}
186.7 & 17.3 \\
17.3 & 56.8
\end{array}\right]\left(\mathrm{kg} \cdot \mathrm{sec}^{2} / \mathrm{cm}\right)} \\
& {[\Phi]=\left[\begin{array}{rr}
1.00 & 1.00 \\
3.90 & -1.06
\end{array}\right]}
\end{aligned}
$$

围有值

$$
\begin{aligned}
& \omega_{1}=5.97 \quad(/ \mathrm{sec}) \\
& \omega_{2}=16.01 \quad(/ \mathrm{sec})
\end{aligned}
$$

減衰定数

$$
\begin{aligned}
& \beta_{1}=0.0031 \\
& \beta_{2}=0.0083
\end{aligned}
$$

ここで, 1 次の減衰定数 $\beta_{1}$ は人力によって煙突を自 由振動させて得られた対数減衰率 $\delta_{1}=0.020$ より

$$
\delta_{1} \doteqdot 2 \pi \beta_{1}
$$

の関係から, $\beta_{2}$ は

$$
\beta_{2}=\beta_{1} \omega_{2} / \omega_{1}
$$

を用いて計算された。

以上の諸元によって，式 (12) の右辺で $\left[S_{f}(\omega)\right]$ を 除くすべてのマトリックスの值が確定したことになる。

\section{4. 風の実測}

\section{（1）風速計}

\section{鉄塔支持型煙突} の周囲の概略を図 -4 に示す。この 図において北から 西方向の風に対し ては障害物らしい ものはない。建物 の高さは $40 \mathrm{~m}$ で あり, 南方向から の風は若干影響を

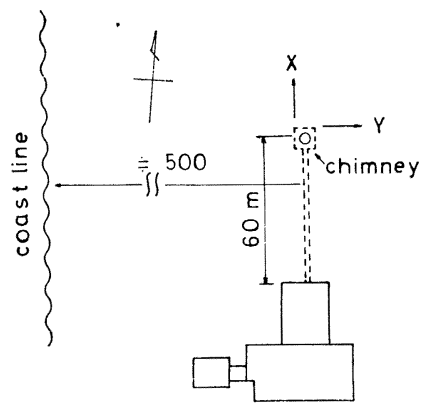

図-4
受けるものと思われる。

風速計（海上電気（株）製品 PA 211）は，図一2 の 地上 $76 \mathrm{~m}$ と $135 \mathrm{~m}$ に設置されていることは前述のと おりである。本風速計は, 超音波風速計と称される型で あり，おもな仕様は次のようである。
測定方向 : $X, Y$ 直交水成 2 成分

測定方式：パルス時間差測定方式

測定範囲 : 0 $\pm 40 \mathrm{~m} / \mathrm{sec}$

分 解 能: $\pm 2 \mathrm{~cm} / \mathrm{sec}$ 以上

精 度: $\pm 3 \%$ 以上

ドリフト：フルスケールの+1\%以下

出 力: $0 \sim \pm 1$ ボル卜

指示方式：メータ一指示

風速計全体の構成は図一5に示寸とおりであって，プ ローブと接続箱とが煙突上に置かれている。各標高とも 風速計設置場所を秋田地方の冬季, 春季の強風が主に北 西の風であることを考慮して,踊場北西端隅としている。

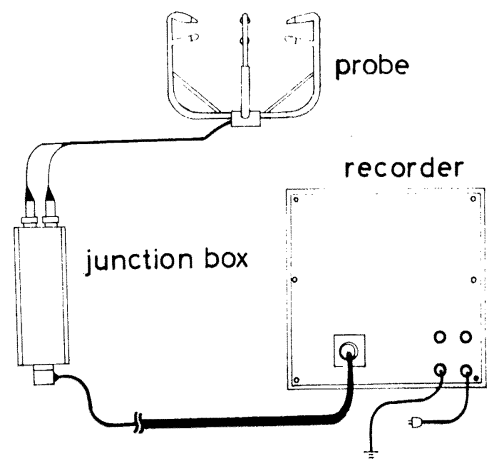

図-5

図一6 に高さ $135 \mathrm{~m}$ で の風速計の位置を示して いるが，煙突表面から風 速計までの距離と筒身径 $(\phi 4.4 \mathrm{~m})$ との比は 0.7 , 高さ $76 \mathrm{~m}$ に掠いては北 西側支柱 $(\phi 0.71 \mathrm{~m})$ の 踊場に設置されていて, 支柱表面から風速計まで の距離と支柱径との比

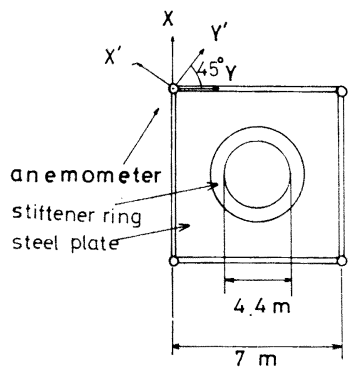

図-6
3 , 筒身径との比 1.7 となっている。

また，加速度計も風速計と同じ高さに設置されてお り，水平直交 2 成分が風速計と同時に測定可能であり， いずれの高さにおいても煙突中心から約 $4 \mathrm{~m}$ の所に置 かれている。

な脑図一6 で $X^{\prime}, Y^{\prime}$ の方向は， $X, Y$ の正の方向と 反時計回りに $45^{\circ}$ 頃いた方向である。これは, 設置場所 の構造上の制約によるものであって，解析にはこれを地 上 $76 \mathrm{~m}$ と同じ方向, $X, Y$ 方向に修正して用いている。

\section{（2）実測}

本報告において 解析されている資料は，1970 年 5 月 2 日のものと (以下「記録 $1 」$ とする), 同年 10 月 26 日 
のもの（以下「記録 2 」する）2 ケースである。記録 は約 5 分間にわたるものであるが，おのおの 200 秒間の 変動が解析に用いられている。図一7(a), (b), 図一8(a), (b) に両記録の風の変動のようすを 10 秒ごとに番号を つけて示している。図中の r.m.s. は標準偏差である。

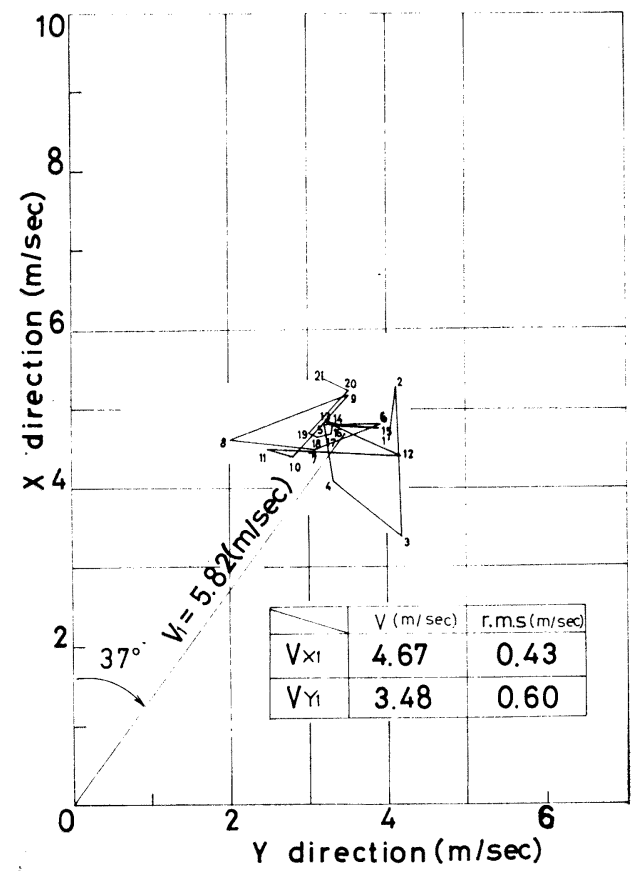

(a) 点 $1(76 \mathrm{~m})$

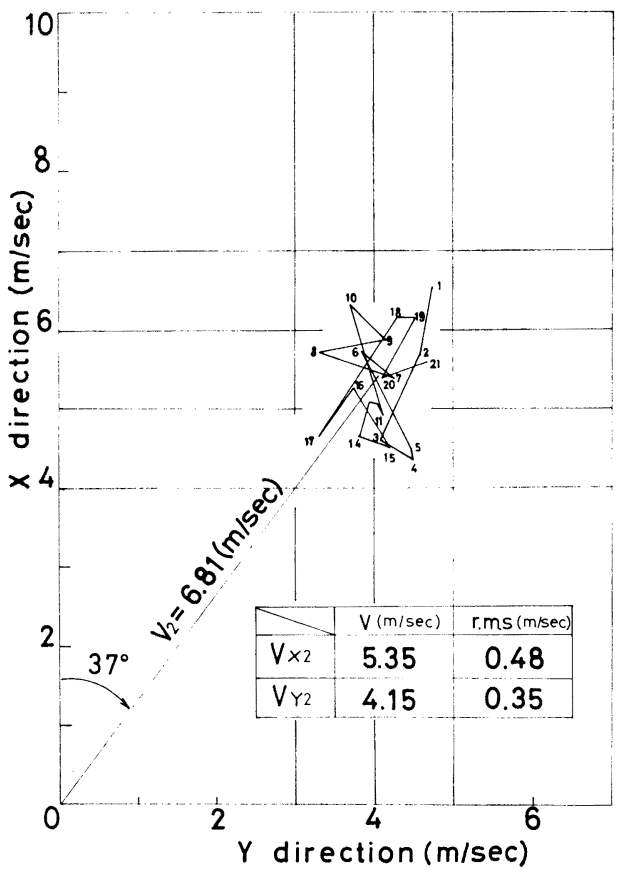

(b) 点 $2(135 \mathrm{~m})$

図一7「記録 1」
これらの図から,「記録 $1 」 の$ 平均風向は南西よりや や南よりの風, 「記録 $2 」$ のそれは北北西からの風で, いずれも建物の影響は少ない方向と思われる。

風速計は気温によって感度が異なり，基準温度は 20 ${ }^{\circ} \mathrm{C}$ であって, 適当な温度補正を要するが, 両記録おの

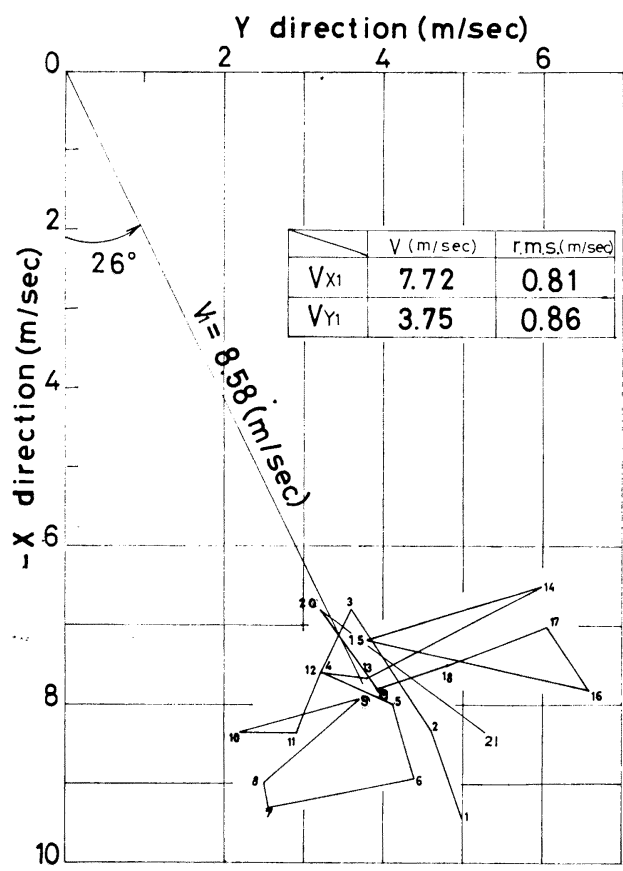

(a) 点 $1(76 \mathrm{~m})$

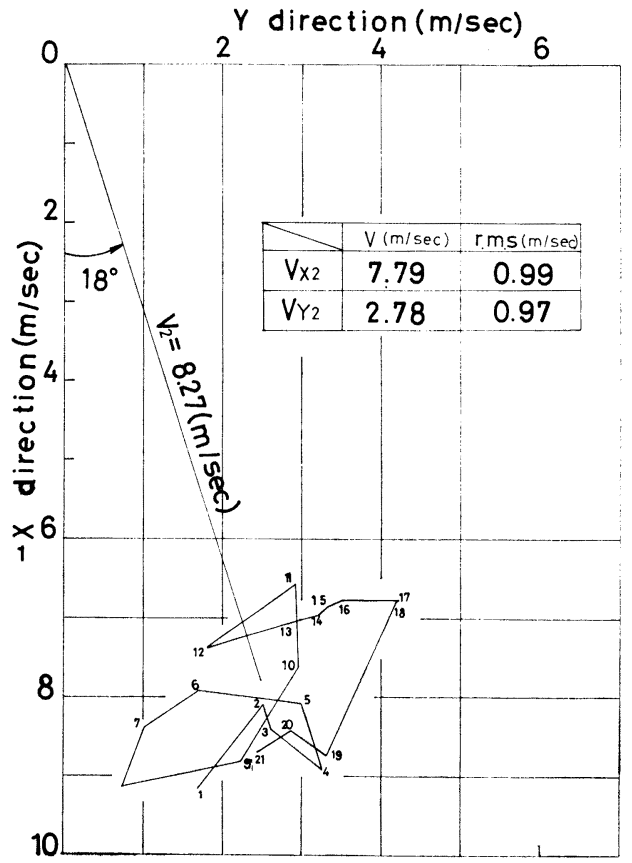

(b) 点 $2(135 \mathrm{~m})$

図一8「記録 2」 


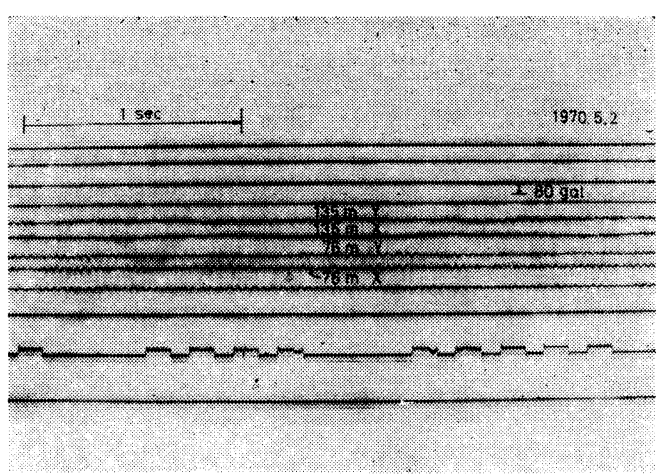

(a)

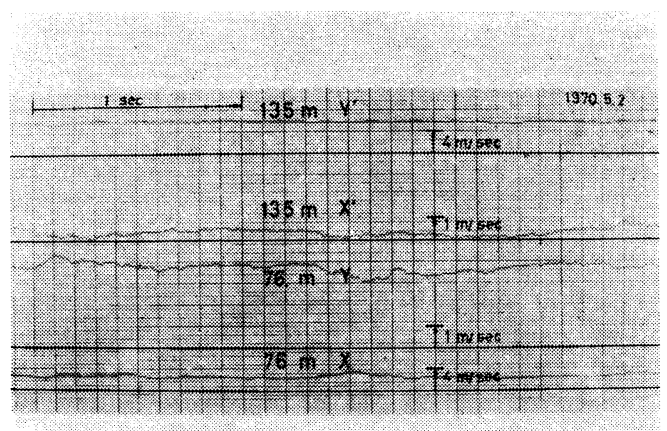

(b)

写共-1

おのの観測当日の最高気温は $21.3^{\circ} \mathrm{C}$ ，および $20.5^{\circ} \mathrm{C}$ で あり，地上 $135 \mathrm{~m}$ 程度では大きな差はないと思われた ので更正は省いている。

風の観測と同時に加速度記録をも得たが，「記録 $1 」 に$ ついて写真-1 (a) に加速度, 写真一1 (b) に風速の記録 の 1 部を示す。写真一1 (a) の加速度記録には 70 100 $\mathrm{c} / \mathrm{sec}$ 程度の不規則な小さな波が重なっているが，この 原因はいまのところよくわかっていない。

\section{5. 実測値の解析と数値計算}

\section{(1) 係 数 $\eta_{i}$}

式（15）を再びかくと，

$$
\eta_{i}=\frac{1}{2} \rho D L_{i} C_{D_{0}} g_{i}(\theta)
$$

無次元倍率 $g_{i}(\theta)$ についてはすでに文献 4) に発表し ている。図一9 にその結果の1部を再掲してある。

「記録 $1 」$ 測点 1,2 に打ける平均風向角は, 図一

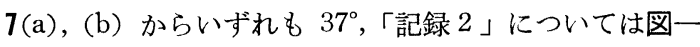
8 (a)，(b) から測点 1 で $26^{\circ}$, 測点 2 で $18^{\circ}$ となってい る。したがって，これらの風向角近傍における $g_{i}(\theta)$ の 変化の度合いは，図一9 から滑らかな部分 $15^{\circ} \sim 45^{\circ}$ に
あることがわかる。特に 幸いともいらべきは， 「記録 $2 」$ は図一8 (a), （b）から風向角の変動は かなりのばらつきを示し ているが, 再び図一9 か ら $15^{\circ} \sim 30^{\circ}$ の区間では $g_{i}(\theta)$ はほとんど一定 となっている。また「記 録 1 」については逆に, 図一9 からややゆるい勾 配の部分にはいっている が, 図一7(a)，(b) から

\begin{tabular}{|c|c|c|}
\hline $\begin{array}{c}\text { mass } \\
\text { point }\end{array}$ & 1 & 2 \\
\hline$d / D$ & 0.17 & 0.08 \\
\hline$d / D$ & 2.95 & 2.31 \\
\hline
\end{tabular}

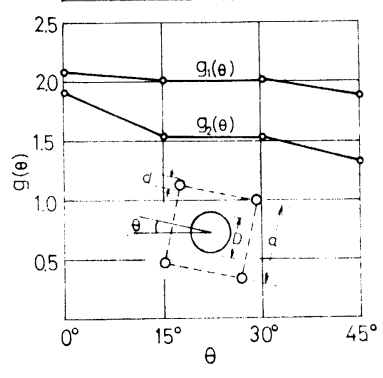

$\left(\operatorname{Re}=2 \sim 6 \times 10^{4}\right)$

図 94)

風向角の変動は小さい。以上から，2.(3) での $g_{i}(\theta)$ 定の仮定を近似的に満足しているものとみなせよう。

次に, 式 (21) における各節点に係る長さ $L_{i}$ は図一 3 (b) に示すようである。 $L_{2}$ には，筒身が露出している 部分 $L_{2}{ }^{\prime}$ と鉄塔で支持されている部分 $L_{2}{ }^{\prime \prime}$ を含んでい るが, $L_{2}{ }^{\prime}$ と $L_{2}{ }^{\prime \prime}$ 部分の抗力係数は不連続に変わるか ら次のように換算した。すなわち, 点 2 に作用する風力 は筒身部において $g_{2}(\theta)=1$ であるから式 (14) によっ $\tau$

$$
\begin{aligned}
F_{2}(t)= & \frac{1}{2} \rho D L_{2}{ }^{\prime} C_{D_{0}} V_{2}^{2}(t) \\
& +\frac{1}{2} \rho D L_{2}{ }^{\prime \prime} C_{D_{0}} g_{2}(\theta) V_{2}^{2}(t) \\
= & \frac{1}{2} \rho D\left(L_{2}{ }^{\prime}+L_{2}^{\prime \prime} \cdot g_{2}(\theta)\right) \cdot C_{D 0} V_{2}^{2}(t)
\end{aligned}
$$

したがって， $L_{2} g_{2}(\theta)$ に相当するものとして,

$$
L_{2} g_{2}(\theta)=L_{2}{ }^{\prime}+L_{2}{ }^{\prime \prime} \cdot g_{2}(\theta)
$$

とおくことができる。

\begin{tabular}{|c|c|c|c|}
\hline \multicolumn{4}{|c|}{ 表一1 } \\
\hline & 定 & 記 録 1 & 記 録 2 \\
\hline 点 1 & $\begin{array}{c}\theta \\
g_{1}(\theta) \\
C_{D_{0}} \cdot g_{1}(\theta) \\
\eta_{1} \\
V_{X_{1}} \\
V_{Y_{1}}\end{array}$ & $\begin{array}{c}37^{\circ} \\
1.9 \\
2.1 \\
39.1 \mathrm{~kg} \cdot \mathrm{m}^{-2} \cdot \mathrm{sec}^{2} \\
4.67 \mathrm{~m} / \mathrm{sec} \\
3.48 \mathrm{~m} / \mathrm{sec}\end{array}$ & $\begin{array}{c}26^{\circ} \\
2.0 \\
2.2 \\
41.1 \mathrm{~kg} \cdot \mathrm{m}^{-2} \cdot \mathrm{sec}^{2} \\
7.72 \mathrm{~m} / \mathrm{sec} \\
3.75 \mathrm{~m} / \mathrm{sec}\end{array}$ \\
\hline 点 2 & $\begin{array}{c}\theta \\
g_{2}(\theta) \\
L_{2}{ }^{\prime}+L_{2}^{\prime \prime} \cdot g_{2}(\theta) \\
\eta_{2} \\
V_{X 2} \\
V_{Y_{2}}\end{array}$ & $\begin{array}{c}37^{\circ} \\
1.4 \\
55.6 \mathrm{~m} \\
16.8 \mathrm{~kg} \cdot \mathrm{m}^{-2} \cdot \mathrm{sec}^{2} \\
5.35 \mathrm{~m} / \mathrm{sec} \\
4.15 \mathrm{~m} / \mathrm{sec}\end{array}$ & $\begin{array}{c}18^{\circ} \\
1.5 \\
58.5 \mathrm{~m} \\
17.7 \mathrm{~kg} \cdot \mathrm{m}^{-2} \cdot \mathrm{sec}^{2} \\
7.79 \mathrm{~m} / \mathrm{sec} \\
2.78 \mathrm{~m} / \mathrm{sec}\end{array}$ \\
\hline 定 数 & $\rho=0.125 \mathrm{~kg}$ & $\mathrm{n}^{-4} \cdot \sec ^{2}, C_{D_{0}}=1.1$ & \\
\hline
\end{tabular}

以上の諸定数を，両記録についてまとめたものが表一 1 である。なお表中には, 式 (19) の風力スペクトルの 計算に必要な $X, Y$ 方向の平均風速 $V_{x i}, V_{y i}$ をもあわ せて記してある(図一7，8 参照)。 


\section{（2） 風速のパワースペクトル}

測点 1 と 2 での, 水平直交 2 成分の風速変動 $v_{x_{1}}, v_{y_{1}}$, $v_{x 2}^{\prime}, v_{y_{2}}$ から式（19）に扔ける互いに独立な 10 種のパ ワースペクトルが求められると, 表一1 の結果と命わせ て風力のスペクトル $\left[S_{f}(\omega)\right]$ が得られる。

2. で表わされている無限積分は実際には有限区間で 行なわれるわけであるが, この際の数値計算や誤差論に ついての詳細は省く ${ }^{5)}$ 。

実測の風速, 加速度ともに解析に用いたのは前述のよ うに 200 秒間であり，これを 0.2 秒ごとに読み取った。 相関関数での $\tau(\mathrm{lag})$ の最大值は, 200 秒間の $10 \%, 20$ 秒とした。したがって, 解析可能な 周波数領域は 0 $2.5 \mathrm{c} / \mathrm{sec}$ までであり $0.025 \mathrm{c} / \mathrm{sec}$ ごとのパワ一值が計 算されている。したがって, 煙突の固有値のほぼ 2 次振 動までを含むことになる。また，スペクトルはハニング (Hanning) のウィンドーによって平滑化されている。

図一10(a)，(b)に「記録1」の風速のスペクトルを， 図一11(a), (b) に「記録 $2 」$ のそれを示してある。図

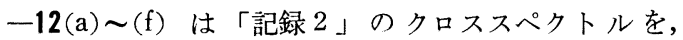

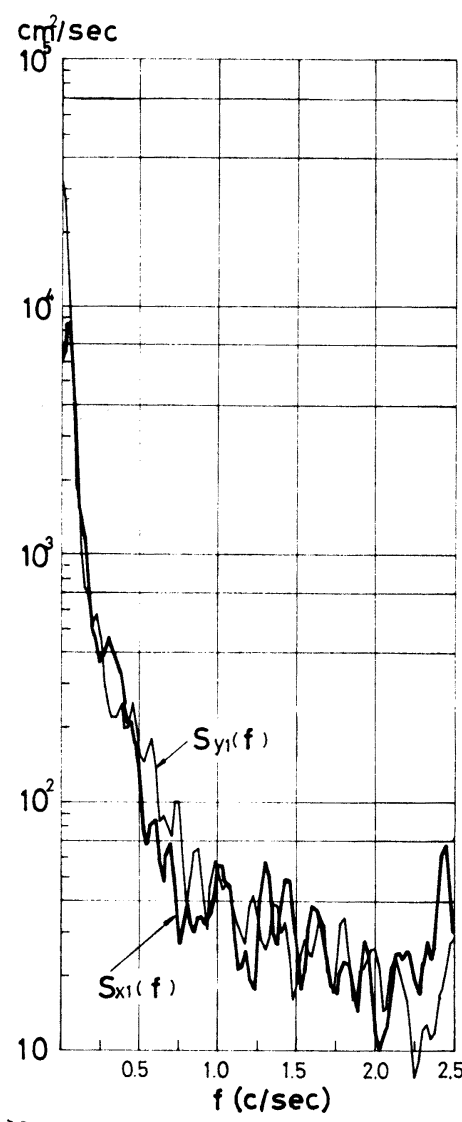

(a) 点 $1(76 \mathrm{~m})$

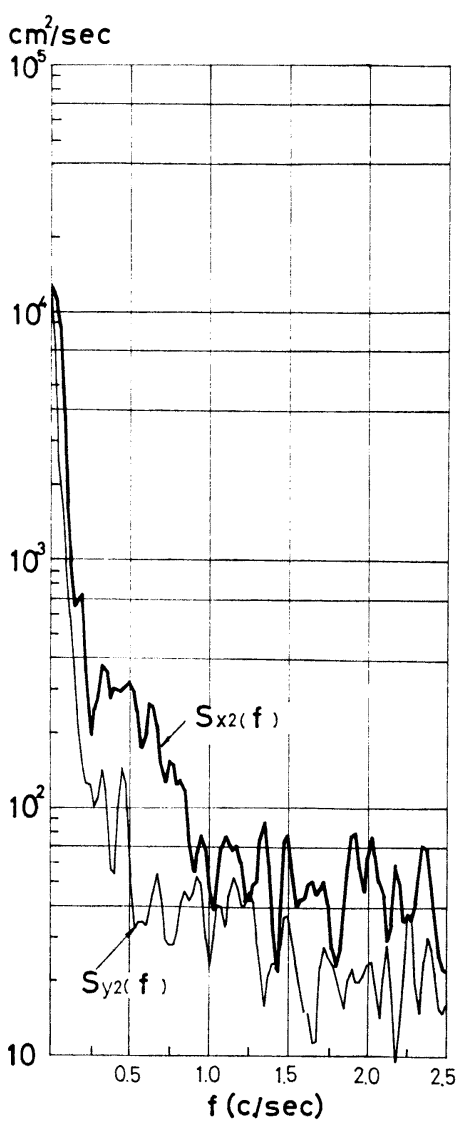

(b) 点 $2(135 \mathrm{~m})$

図一10「記録 1」

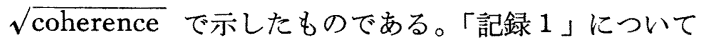
は，「記録 $2 」 の$ 場合と類似しているので省略した。な お，これらの図の縦軸の記号は式（19）における10 種 のスペクトルの記号に合致する。たとえば，「記録 $2 」$ については図一11(a), (b) は, 10 種のちち $\left(S_{x i x i}(\omega)\right.$ を $S_{x i}(\omega)$ などとかくことにして） $S_{x_{1}}(\omega), S_{y_{1}}(\omega)$, $S_{x_{2}}(\omega), S_{y_{2}}(\omega)$ を, 図一12(a)〜(f) は, 残りの 6 種の クロススペクトル $S_{x_{1} y_{1}}(\omega), S_{x_{2} y_{2}}(\omega), \cdots, S_{y_{2} x_{1}}(\omega)$ を 示している $(\omega=2 \pi f)$ 。

図一10,11 から，いずれの測点においても低周波数で のパワーが大きい。この点, 強風のスペクトルと類似し ている。また，高さによるパワー值の差は顕著でない。 これは, 弱い風であることと，地上の障害物（したがっ て粗度）が少ないことによるものと思われる。また, 図 -11の值は図一10 の值より全体的に大きい。これは, 前者の平均風速が後者より大きいからであり, この点も 強風のスペクトルと似ている(6),77,8)。

$\sqrt{\text { coherence }}$ に関しては, 図一12 において同じ高さ での 2 成分間の值はほかの組み合わせより大きい（(a), (b))。また, 異なる高さでの同じ方向の組み合わせ ((c), (d)), 高さと方向がともに異なる成分 の組み合わせ $((\mathrm{e}),(\mathrm{f}))$ については, 低周波数部で急速に值が減少している が (次節式 (25) 参照), 高周波数部で は不規則な变化をしている。

\section{（3）加速度の実測值と計算值に 関する考察}

図一13(a)〜 (d) は，「記録 $1 」$ につ いての加速度応答スペクトルの実測值 と理論計算值の比較, 図一14(a) ( d)

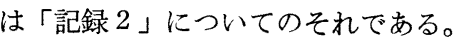
図中破線は, 前節 2.の 10 種のスペ クトルと表一1 の結果を用いて式(19) により $\left[S_{f}(\omega)\right]$ を計算し，これと 3. での構造諸元を用い式 (12) によって 計算されたものである。図中の実線 は, 風速の場合と同様に加速度記録を 0.2 秒ごとに読み取りスペクトル解析 を行なったものである。これらの結果 について以下考察を加えてみたい。

1）スペクトルのピークの位置から 固有 1 次振動数は $0.92 \mathrm{c} / \mathrm{sec}$ であり, 2 自由度としての計算値 $0.96 \mathrm{c} / \mathrm{sec}$ に ほぼ等しい。

2）実測スペクトルは，1 次振動数 以外の部分においても計算値に比べて 


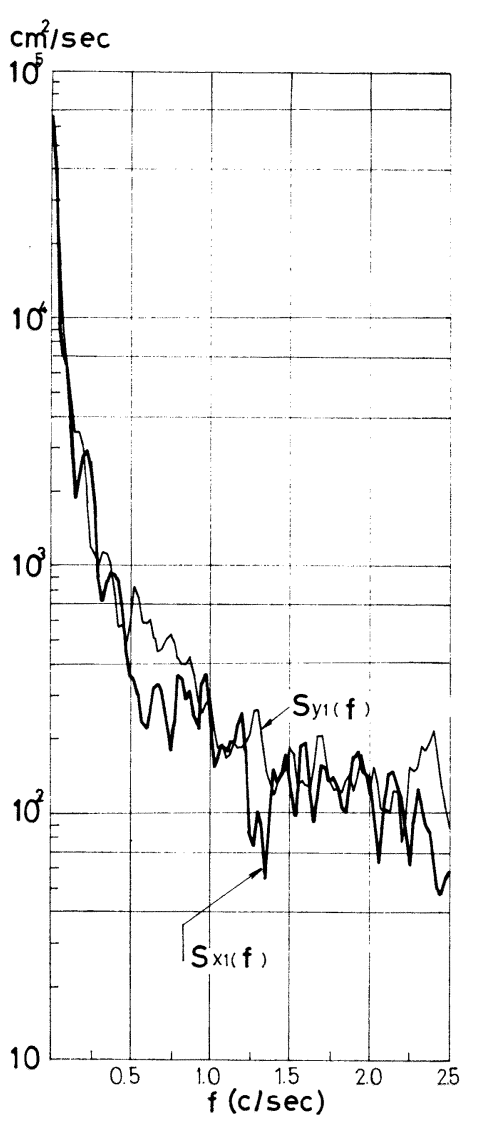

(a) 点 $1(76 \mathrm{~m})$

図-11

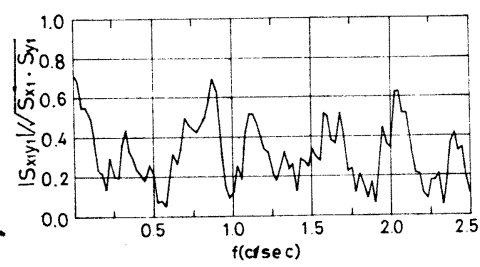

(a)

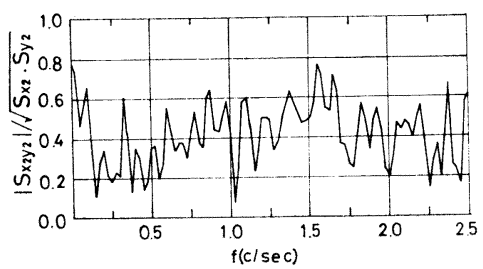

(b)

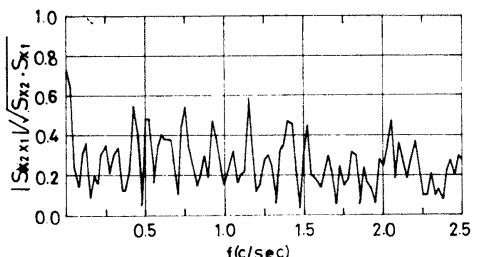

(c) $\mathrm{cm}^{2} / \mathrm{sec}$
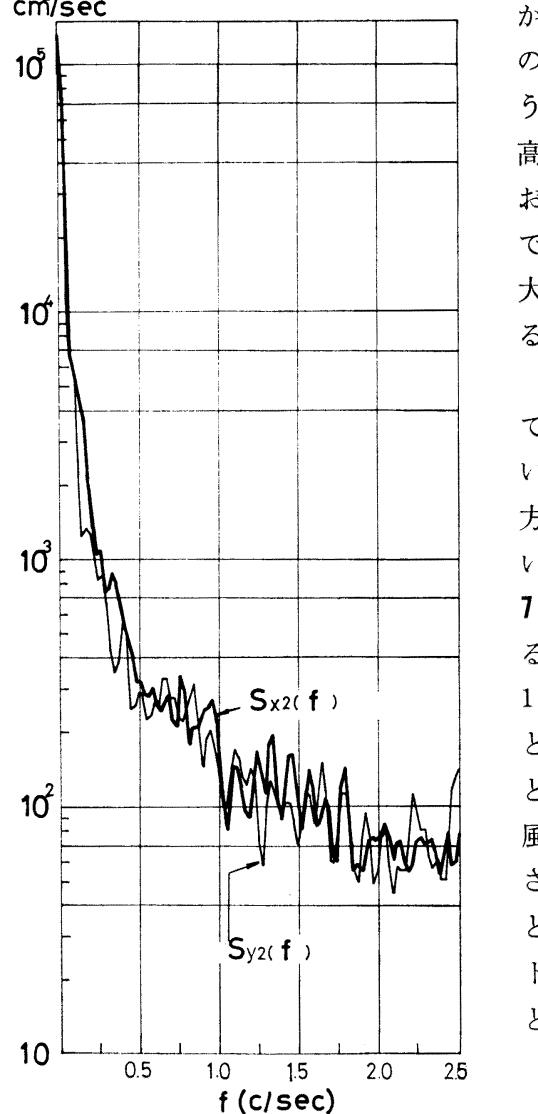

(b) 点 $2(135 \mathrm{~m})$

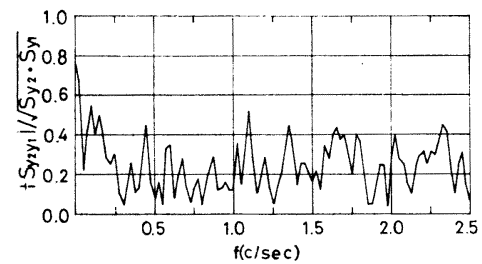

(d)

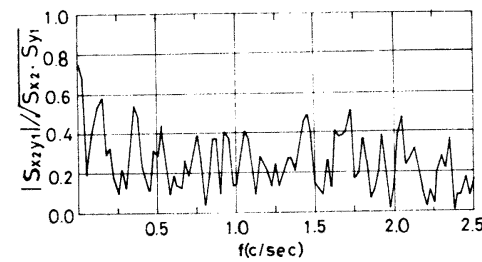

(e)

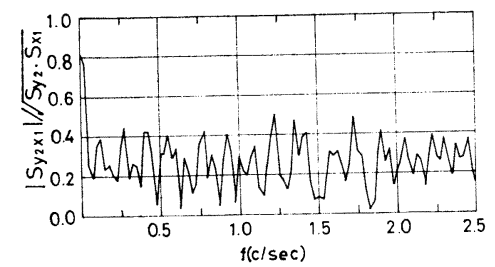

(f)

かなり大きな值を示している。こ の原因として，4.(2) でふれたよ 5に加速度記録 写真一1 (a) には 高周波の不規則な変動が混入して 拈り, 特に地上 $76 \mathrm{~m}$ (測点 1 ) ではその変動幅も煙突全体の值と 大差ないことによるものと思われ る。

3) 測点 1，2 のいずれにおい ても，固有 1 次振動数の近傍に拉 いては実測值と計算值ともに $X$ 方向の值が $Y$ 方向の值より大き い。これは，表一1（または図一 7,8）から測点 2 の平均風速でみ ると, 「記録 1 」では $V_{x_{2}} / V_{y_{2}}=$ 1.3 ,「記録 $2 」$ 」゙は $V_{x_{2}} / V_{y_{2}}=2.8$ と $X$ 方向の平均風速が大きいこ とによる。逆に，この程度の弱い 風では風向直角方向の励振力は小 さいものと判断できよう。このこ とは, 本煙突の予想臨界風速がス トローハル数を 0.2 , 代表的寸法 として筒身外径をとると

$$
\begin{aligned}
V_{c r} & =f \cdot D / S \\
& =0.91 \times 4.4 / 0.2 \\
& =18.2(\mathrm{~m} / \mathrm{sec})
\end{aligned}
$$

であり,これに対して両記録とも に $10 \mathrm{~m} / \mathrm{sec}$ 以下の弱い風である ことと関連するものと思われる*。

4) ピークの值は, 計算值が実 測值をかなり上まわっている。こ の理由として以下の 2 点が考えら れる。

1つには，2.(3) でふれたよう に空力アドミッタンスを 1 と仮定 していることによるものである。 Davenport ${ }^{9)}$ は吊橋の不規則振動 論に関連して**

$$
C(\xi)=\frac{4}{(7 \xi)^{4}}\left[7 \xi-1+e^{-7 \xi}\right]^{2}
$$

を提案している。式 (23) は強風

*「記録 $1 」$, 「記録 2」の風速域では レイノルズ数が $(1.5 \sim 2.6) \times 10^{6}$ の 範囲にあり, 静止円柱で渦の周期性 がなくなる超臨界域にあることも注 目される。

**原著の式には印刷上のミスと思われ る点があるので修正してかく。 
の主流直角方向の 2 点間のコヒーレンスに関する実験式

$$
\mid S_{12}(\omega) / \sqrt{S_{1}(\omega) S_{2}(\omega)}=e^{-k \Delta X f / V}
$$

を用いて補剛トラス形式の吊橋の横断面で平均したもの
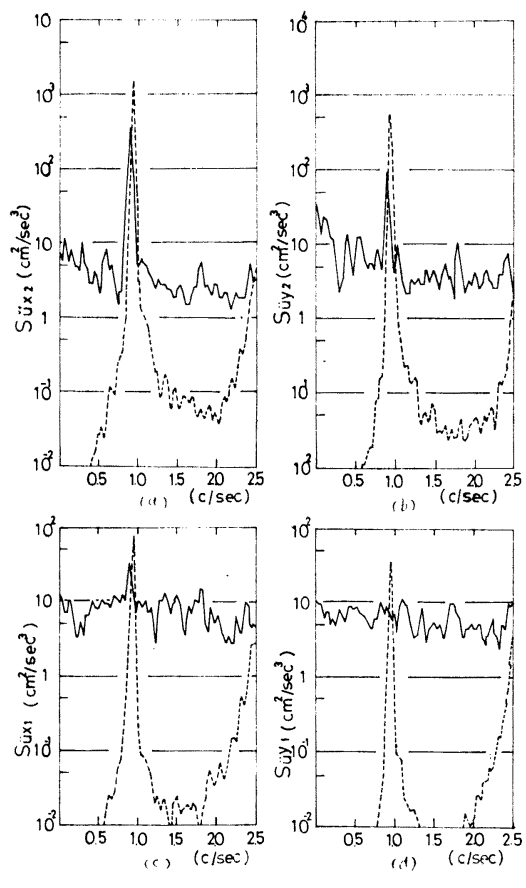

図-13 ……: 計算值

「記録 1 」

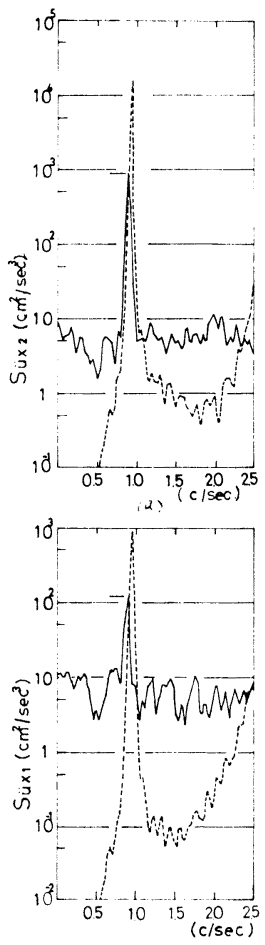

(c)

: 実測值

图-14
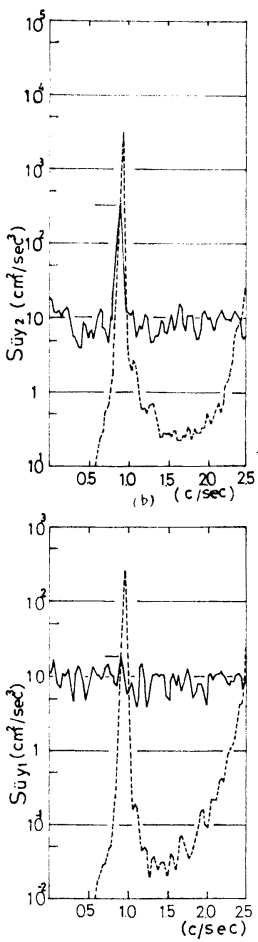

(d)

....... : 計算値

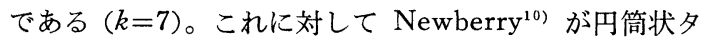
ワーの風圧変動に関連して述べているように, 鉄塔支持 型煙突のような中実断面の場合には風下側後流の死水域 に接する煙突表面に対しては自然風の 空間相関式 (24) を適用できないのは明白である。一般に後流側表面の風 圧変動は風上側のそれよりも式 $(24)$ における $k$ の值が 小さい,つまり相関が高い(たとえば ${ }^{11}$ 矩形断面のビル の風上側で $k \doteqdot 7.3$, 後流域で $k \doteqdot 2.6)$ 。著者らはこの点 についての資料をまだ得ていないが，上述の事柄から風 速変動の横方向の相関が 1 つ目安となろら。すなわち $C(\xi)$ として

$$
\begin{aligned}
C(\xi) & =\int_{0}^{D} \int_{0}^{D} e^{-k f\left|X-X^{\prime}\right| / V} d X d X^{\prime} \\
& =\frac{2}{(7 \xi)^{2}}\left[7 \xi-1+e^{-7 \xi}\right] \ldots \ldots .
\end{aligned}
$$

ここに $k=7$ である。たとえば，「記録 $1 」 の$ 点 $2(135$ m) では 1 次モードに対して

$$
\xi=0.96(\mathrm{c} / \mathrm{sec}) \times 4.4(\mathrm{~m}) / 6.81(\mathrm{~m} / \mathrm{sec})=0.62
$$

$\therefore \quad C(\xi)=0.36$

で約 2 倍強大きめに風力を評価していることになろらが 風圧変動については今後の研究にまたねばならない。

2 つには煙突の高さ方向の評価に起因するものであ る。もちろん異なる高さ 2 点での 3 次元空間相関は計算 に含まれている。図一3(b) で点 1,2 に寄与する長さ をおのおの $L_{1}, L_{2}$ と評価しているのであるが，このよ らな片持ばり構造にあっては自由端近傍の（点 2 の) 風 速変動が系の応答に支配的であるから特に区間 $L_{2}$ 内に て相関 1 とすることは応答スペクトルを大きめに見積る ことになろら。ただ, 図一13(c)〜 (f) から高周波数部で はかならずしも式 (24) のよらに空間相関が単調に減少 していないので, どの程度大きめに見積っているか定量 的な検討は困難である。

これら 2 つの理由から, 結局計算值は上界に近い值を 与えていると思われる。

以上の困難性は，実際に測定されたスペクトルを用い る場合は, 測定点の数を増す以外現在の時点では避けら れそらにないように思われる。

耐風設計上の観点から興味あるのは応答変位スペクト ルであるが，風速のパワーは低周波数部で高いことを考 虑し, かつ2. (1) から応答速度スペクトルは周波数の 2 乗に, 加速度スペクトルは 4 乗に比例するので, 変位, 速度, 加速度応答の変動風に対する感度は高周波数にな るにつれてこの順であり, 低周波数になるにつれて逆の 順になることに留意する必要があろう。

\section{6. 結語}

本報告では実在の鉄塔支持型煙突を対象として，予想 
臨界風速以下の風に対して不規則振動論の立場から加速 度応答の実測值と計算値との比較考察を行なってみた。 測定された風が弱いために, 耐風工学上よりも不規則振 動論の実構造物への応用といら意味での資料になると思 らが, 得られた結果と問題点を要約すると次のようであ る。

（1）その限界は明瞭ではないが, 弱い風の場合は鉄 塔支持型煙突の挙動は不規則振動論の立場から解釈可能 であり，動的揚力は大きくないといえよう。

（2）今後の問題点として，鉄塔支持型煙突のような トラス構造と中実構造（煙突筒身）とから成る断面に対 する空力アドミッタンスを合理的に決定することが望ま れる。さらに, 煙突の高さ方向についても, 有限の点で 実測された変動風を集中力系として評価する場合, 解析 された多点間のクロススペクトルから測定点以外のスペ クトルもしくは相関を推定する手法（たとえば内挿法の ような）が確立されるならば, より正確な解析を行なう ことができよう。

終りに, 本研究は東北電力 (株) 取締役 吉田栄延氏 の御理解ならびに同社秋田火力発電所関係者皆様の御協 力に負らところ大であり, 記して感謝の意を表します。

なお, 本研究の一部は昭和 44 年度文部省科学研究費 (試験研究)によったものであり, 関係の方がたにあわ せて謝意を表します。

また計算は東北大学大型計算センターを利用したこと を記します。

参考文 献

1) Davenport, A.G. : The spectrum of horizontal gust- ness near the ground in high wind, Quat. J.R. Met. Soc., Vol. 87, April 1961

2）石崎湀雄・ 川村純夫 : 風圧力の変動と鉄塔構造物の振動 （I），日本建築学会論文報告集 143 号，1967-4

3）代表的なものとして

Crandall, H. : Rondom Vibration, Academic press, 1963

Lin, Y.K. : Probablistic Theory of Structural Mechanics, McGrow-Hill, Inc. 1967

Bolotin, V.V. : Statistical Method in Structural Mechanics, translated by Samuel Aroni, Holden-Day, Inc. 1968

4）色部誠・薄木征三・市田孟史・工藤研二：鉄塔支持型䙳 突の部分模型に対する風洞实験, 土木学会 26 回年次学術 講演会講演集, 第 I 部門 115, 1967-10

5）下記の文献を参考とした

Blackman, R.B. and Tukey, J.W. : The Measurement of Power Spectra, Dover Pub. Inc. 1959 本間 仁編: 数值解析 - 水文観測, 态用水理学 下 II, pp. $81 \sim 137$, 丸善出版

6) 前出 1)

7) 日野幹雄: 瞬間最大值と 評価時間の関係, 土木学会論文 集 117 号, 1965-5.

8）塩谷正雄・新井秀雄：德島県那賀川海岸における強風の 観測, 構造物の耐風性に関する第 1 回シンポジウム論文 集, 1970

9) Davenport, A.G. : Buffetting of a Suspension Bridge by Storm Wind, Proc. A.S.C.E., Vol. 88, 1962

10) Newberry, C.W., Eaton, K.J. and Mayne, J.R. : Wind Pressures on the Post Office Tower, London, pp. 247, Proc. Wind Effects on Buildings and Structures, Tokyo 1971

11) Robert, L.P. : Dynamic Response of a Tall Building to Random Wind Loads, pp. 436, Table 2. (Monsoon), Proc. Wind Effects on Buildings and Structures, Tokyo 1971

$\left(\begin{array}{l}1971.11 .18 \cdot \text { 受 } \text { 付 } \\ 1972.7 .14 \cdot \text { 再受付 }\end{array}\right)$ 